\title{
ANALISIS NILAI DAN PENGETAHUAN IBU-IBU RUMAH TANGGA SEBAGAI PREDIKTOR INTENSI BELI PRODUK SAYURAN ORGANIK DI PASAR MODERN KOTA PEKANBARU
}

\author{
Elfi Rahmadani dan Penti Suryani \\ Fakultas Pertanian dan Peternakan UIN Suska Riau \\ Email:elfirahmadani@yahoo.co.id
}

\begin{abstract}
This study was conducted at three sites of the modern market, in District Tampan and Payung Sekaki. The purpose of the study was to determine the characteristics and socio-economic conditions of the mother-housewife who buy organic vegetable products in the modern market Pekanbaru, and seek and reduce exploratory factor that can explain the influence of purchasing intentions housewife to organic vegetables. This study tested simultaneously and partially of predictor variables were examined to the intention to buy organic vegetable products in accordance with the design of the model. Descriptive quantitative research method is using factor analysis and path analysis. The study was conducted by a survey and interviews with respondents using questionnaires. Sampling was done by the method of accidental sampling a number of 103 respondents each of 3 modern market. The results showed all hypothesis is accepted. The main factors that influence the cost of the purchase of vegetables, the age of the buyer, the number of family members buyers, and home ownership, then the second factor of the level of education and the third factor the amount of consumption of vegetables. Knowledge of organic crops have a positive and significant impact on the attitude of the organic vegetables. Variable value of the natural orientation and attitude to the intention to buy organic vegetables have validity and reliability of the positive value. Organic Knowledge also has a positive and significant impact on the attitude of organic vegetables. Attitudes on organic vegetables also have a positive and significant impact on the purchasing intentions of organic vegetables.
\end{abstract}

Keywords:organic vegetables, social economic condition, characteristic, value orientation of human experience, knowledge of organic, buying intention

\footnotetext{
Abstrak:Penelitian ini dilakukan pada tiga lokasi pasar modern, di Kecamatan Tampan dan Payung Sekaki. Tujuan penelitian adalah mengetahui karakteristik dan kondisi sosial ekonomi ibu-ibu rumah tangga yang membeli produk sayuran organik di pasar modern Kota Pekanbaru, serta mencari dan mereduksi faktor eksploratori yang mampu menjelaskan pengaruh intensi beli ibu rumah tangga terhadap sayur organic. Penelitian ini melakukan pengujian secara simultan dan parsial dari variabel prediktor yang diteliti terhadap intensi beli produk sayuran organik sesuai dengan rancangan model. Metode penelitian adalah deskriptif kuantitatif menggunakan analisis faktor dan analisis jalur. Penelitian dilakukan dengan survei dan wawancara kepada responden menggunakan kuisioner. Pengambilan sampel dilakukan dengan metode accidental sampling sejumlah masing-masing 103 responden dari 3 pasar modern. Hasil penelitian menunjukkan semua hipotesis diterima. Faktor utama yang berpengaruh adalah biaya pembelian sayur, usia pembeli, jumlah anggota keluarga pembeli, dan kepemilikan rumah, selanjutnya faktor kedua tingkat pendidikan dan faktor ketiga banyaknya konsumsi sayur. Pengetahuan akan tanaman organik memiliki pengaruh positif dan signifikan terhadap sikap pada sayuran organik. Variabel nilai orientasi alami dan sikap terhadap intensi beli sayur organik memiliki validitas dan nilai realibilitas yang positif. Pengetahuan
} 
Elfi Rahmadani dan Penti Suryani: Analisis Nilai dan Pengetahuan Ibu-ibu Rumah Tangga sebagai Prediktor Intensi Beli Produk Sayuran Organik di Pasar Modern Kota Pekanbaru

organik juga memiliki pengaruh positif dan signifikan terhadap sikap pada sayuran organik. Sikap pada sayuran organik juga memiliki pengaruh positif dan signifikan terhadap intensi beli sayuran organik.

Kata Kunci: sayuran organik, kondisi sosial ekonomi, karakteristik, nilai orientasi alami manusia, pengetahuan organik, intensi beli

\section{PENDAHULUAN}

Konsumsi sayuran di Indonesia tidak meningkat dari tahun ketahun, hal ini terlihat dari data FAO tahun 2014 yang menjelaskan bahwa masyarakat Indonesia setiap tahunnya tidak pernah meningkat dalam konsumsi sayuran dan hanya mengkonsumsi sayuran 35 $\mathrm{kg} /$ tahun/perkapita, sedangkan anjuran dari organisasi pangan dan pertanian dunia (FAO) adalah $75 \mathrm{~kg}$ perkapita pertahun. Data ini bertolak belakang dengan negara Cina yang menunjukkan data konsumsi sayuran $270 \mathrm{~kg}$ perkapita pertahun. Padahal dimasyarakat modern, pola hidup sehat merupakan salah satu ukuran standar kualitas hidup. Minat masyarakat Indonesia dalam mengkonsumsi makanan organik masih sangat rendah. Hal ini sesuai dengan hasil survei penelitian YLKI terhadap 609 responden di beberapa wilayah Jakarta yang menunjukkan konsumen dalam mengkonsumsi bahan organik seperti: beras organik hanya sebesar $24 \%$, mengkonsumsi buah-buahan dan sayuran segar sebesar $17 \%$ dan dalam bentuk bumbu-bumbu sebesar 3\%. ${ }^{1}$ Adapun alasan konsumen/ masyarakat tidak membeli pangan organik adalah disebabkan harga yang mahal, keterjangkauan dan akses tempat yang masih sangat sulit.Dari semua responden penelitian maka 34\% responden beralasan tidak membeli pangan organik karena tidak mengetahui tentang pentingnya pangan organik. Dari penelaahan penelitian oleh YLKI tersebut menunjukkan masih rendahnya konsumsi pangan organik di Indonesia. Masalah akses dan keterjangkauan masih menjadi persoalan utama konsumen jika ingin mendapatkan produk pangan organik. Minimnya informasi, terkait tempat penjualan dengan harga yang terjangkau merupakan salah satu masalah yang harus dicarikan jalan keluarnya. Selama ini sebagian besar konsumen membeli produk pangan organik di ritel modern dan sedikitnya sekali jumlah produsen yang menawarkan produk tersebut di pasar tradisional, akibat terkait dengan minimnya konsumen yang membeli produk makanan organik.

Pemahaman faktor-faktor yang berperan menjelaskan perilaku membeli makanan organik diharapkan mampu mengurangi degradasi lingkungan melalui aspek konsumsi yang ramah lingkungan. Perilaku beli makanan organik dapat dijadikan sebagai sasaran dalam mengarahkan konsumsi yang 
ramah lingkungan serta perbaikan mutu hidup. Pentingnya pemahaman perilaku beli makanan organik dari sisi konsumen antara lain alasan kesehatan, kualitas hidup maupun alasan mengurangi degradasi lingkungan². Dari sisi pemasar, menurut Kalafatis dkk, pemahaman perilaku beli makanan organik penting sebagai bagian dari komunikasi dan strategi pemasaran bagi segmen yang potensial ${ }^{3}$.

Beberapa studi perilaku konsumen berupaya mengidentifikasi faktor-faktor yang berperan bagi perilaku konsumen sayuran organic. Studi-studi tersebut mencoba mengeksplorasi variabel-variabel yang menjadi anteseden yang berperan menjelaskan perilaku pembelian sayuran organic yaitu nilai konsumen (Chan, 2001; Chan \& Lau, 2000; Fraj \& Martinez, 2006; Junaedi, 2007; Sihombing, 2007), pengetahuan (Chan, 1999; Chan \&Lau, 2000; Laroche et al., 2001; Magistris \& Gracia, 2008), sikap konsumen (Aertsens et al., 2009; Chiou, 1998; Kalafatis et al., 1999; Lodorfos \& Dennis, 2008; Maloney \& Ward, 1973; Suprapto \& Wijaya, 2012).Perilaku juga eratkaitannya dengan kualitas lingkungan hidup serta sangat bergantung pada tingkat pengetahuan, sikap dan nilai yang ada padakonsumen sebagai umatmanusia (Chen \& Chai, 2010).

Nilai dan pengetahuan merupakan faktor yang esensial yang perlu dipertimbangkan dalam penelitian perilaku konsumen pangan organic. Kalafatis et al (1999) dalam penelitiannya yang menggunakan model dasar teori perilaku terencana menyarankan perlunya melibatkan sejumlah orientasi budaya berupa nilai-nilai personal lainnya dalam memperediksi intensi beli makanan organic.Chiou dalam penelitiannya mengenai intensi beli makanan organicjugamerekomendasikan perlunya mempertimbangkan tekanan sosial dan orientasi budaya atau nilai yang berbeda dalam memprediksi intensi beli makanan organic ${ }^{4}$.Aertsens et al ${ }^{5}$ dalam menelaah sejumlah determinan aspek dasar yang mendasari perilaku konsumsi sayuran organicmenyarankan pentingnya mempertimbangkan aspek nilai sebagai determinan dalam memprediksi perilaku beli makanan organic.

Konsep tentang makanan dan nutrisi memiliki nilai sosial, karena pilihan personal dipengaruhi oleh nilainilai personal dan nilai-nilai yang diakui lingkungan social.Hal ini sesuai dengan hasil penelitian Fotopoulus \& Krystallis ${ }^{6}$.Lebih lanjut, Engel dan kawan-kawan, serta Fraj dan Martinez mengemukakan bahwa nilai-nilai merupakan variabel psikografis yang menjadi orientasi perusahaan dalam mengidentifikasi segmentasi konsumen untuk produk-produk ramah lingkungan ${ }^{7}$. Nilai sering digunakan oleh pemasar dalam mengidentifikasi perilaku konsumen ramah llingkungan. Nilai-nilai dipertimbangkan sebagai 
Elfi Rahmadani dan Penti Suryani: Analisis Nilai dan Pengetahuan Ibu-ibu Rumah Tangga sebagai Prediktor Intensi Beli Produk Sayuran Organik di Pasar Modern Kota Pekanbaru

suatu variabel penting dalam memahami perilaku konsumen, karena nilai mengahadirkan tujuan fundamental yang dicari oleh konsumen, yang berguna untuk pemuasan bagi segmen mereka ${ }^{8}$.

Selain aspek nilai, aspek pengetahuan konsumen pada produk juga perlu dipertimbangkan dalam penelitian perilaku konsumen karena berkaitan dengan pertimbangan pembelian.Lodorfos \& Dennis ${ }^{9}$ menyarankan pentingnya informasi sebagai dari pengambilan keputusan konsumen organic.Aspek pengetahuan merupakan aspek yang mempengaruhi perilaku pembelian menurut Engel dan kawan-kawan ${ }^{10}$, perilaku pencarian infomasi menurut Brucks ${ }^{11}$ dan membantu konsumen mempelajari produk baru.Sikap yang menjadi komponen dasar dalam teori perilaku terencana ditentukan oleh tingkat keyakinan individu dan dapat berubah sesuai dengan tingkat pengetahuan ${ }^{12}$. Aspek pengetahuan produk menjadi salah satu pertimbangan konsumen dalam mengevaluasi produk. Pengetahuan produk menunjukkan seberapa besar informasi produk yang telah diserap oleh konsumen ${ }^{13}$.

Penelitian yang dilakukan akan mempertimbangkan nilai konsumen yang berorientasi alami manusia dan pengetahuan organic, dalam memprediksi intensi beli makanan organic. Sebagai suatu fenomena dalam perilaku konsumen, produk makanan masih membutuhkan kajian lebih mendalam untuk memperoleh kepercayaan dan legitimasi konsumen. Dengan demikian makanan organik penting untuk dipahami oleh pemasar sebagai dasar dalam mengembangkan komunikasi yang efektif. Adapun tujuan dari penelitian ini adalah menguji pengaruh simultan dan parsial dari dari variabel prediktor yang diteliti terhadap intensi beli pangan organik sesuai dengan rancangan model yaitu pengaruh variabel nilai orientasi alami manusia dan pengetahuan organic terhadap intensi beli melalui sikap pada produk sayuran organik.Perilaku konsumen yang membeli produk sayuran ini menarik untuk diteliti, sehingga penulis melakukan penelitian mengenai:" Analisis Nilai dan Pengetahuan Ibu-Ibu Rumah Tangga Sebagai Prediktor Intensi Beli Produk Sayuran Organik di Pasar Modern Kota Pekanbaru."

\section{Hipotesis}

Hipotesis dalam penelitian ini adalah:

H1: Faktor utama yang diperhitungkan pada preferensi konsumen terhadap intensi beli produk sayuran organik di pasar modern Kota Pekanbaru adalah biaya pengeluaran untuk mengkonsumsi sayur organik usia pembeli, jumlah anggota keluarga pembeli, dan kepemilikan rumah. 
H2: Pengetahuan organik berpengaruh positif terhadap sikap pada makanan organik.

H3: Sikap pada makanan organik berpengaruh positif terhadap intensi beli makanan organik.

H4: Nilai orientasi alami ibu rumah tangga berpengaruh positif terhadap sikap pada makanan organik.

\section{METODOLOGI PENELITIAN}

\section{Waktu, dan Tempat}

Penelitian ini dilakukan pada 3 pasar modern yang terdapat di Kecamatan Tampan, dan Payung Sekaki) dan berlangsung di bulan Agustus sampai November 2014. Adapun pasar modern yang dipilih sebagai lokasi penelitian adalah Giant, Hypermart dan Lotte Mart. Pemilihan lokasi dilakukan secara sengaja (purposive) dengan pertimbangan: (1) Produk sayuran tersedia di ketiga pasar modern tersebut (2). Kualitas produk relatif lebih baik dan suasana berbelanja nyaman. MenurutSingarimbun danEffendi (1989), penentuan lokasi penelitian dilakukan secara sengaja atau purposive dengan berdasarkan pertimbangan tertentu.

\section{Jenis dan Sumber Data Penelitian}

Pengambilan data dalam penelitian ini dilakukan dengan wawancara, pencatatan dan observasi Jenis data yaitu primer dan sekunder. Data primer adalah data yang diperoleh langsung dari responden penelitian (ibu-ibu rumah tanggayang berbelanja di 3 pasar modern yaitu Giant, Hypermart, dan Lotte Mart melalui wawancara dengan menggunakan daftar pertanyaan/kuisioner yang terkait faktorfaktor yang mempengaruhi responden dalam membeli sayur organik diantaranya karakteristik responden, kondisi sosial, ekonomi, variabel intensi beli sayur organik, variabel sikap dan pengetahuan terhadap sayur organik). Sementara, data sekunder terdiri dari dari profil lokasi penelitian, profil kecamatan tempat berdirinya pasar modern, data BPS serta data pendukung lainnya.

\section{Teknik Pengambilan Sampel}

Teknik pengambilan sampel adalah dengan metode accidental sampling, dimana sampel penelitian didapatkan ketika peneliti berada di tempat penelitian untuk menyebarkan kuisioner ataupun wawancara dan berdasarkan kemudahan bagi peneliti dengan cara mewawancarai konsumen yang sedang membeli sayuran dipasar modern tersebut secara sengaja/ langsung. Sugiyono (2005) menjelaskan accidental sampling adalah teknik pengambilan sampel secara tidak sengaja atau secara acak. Selanjutnya Frendy (2011) dalam Mustain (2012) menambahkan, bila dalam populasi penelitian tidak diketahui secara pasti, maka dapat digunakan teknik sampling kemudahan. Selanjutnya berdasarkan sampling kemudahan ini, peneliti 
Elfi Rahmadani dan Penti Suryani: Analisis Nilai dan Pengetahuan Ibu-ibu Rumah Tangga sebagai Prediktor Intensi Beli Produk Sayuran Organik di Pasar Modern Kota Pekanbaru

menyeleksi sampel dengan menyaring kuesioner yang ada.

Adapun kriteria konsumen yang akan dijadikan responden penelitian ini adalah: konsumen yang berdomisili di Kecamatan Tampan dan Kecamatan Payung Sekaki, konsumen melakukan pembelian sayur organik di pasar modern yang menjadi fokus penelitian, jika terdapat satu rombongan keluarga hanya diambil satu orang yang untuk sampel penelitian untuk mengisi satu kuesioner. Operasional teknis wawancara dilakukan satu persatu yang mana satu konsumen diwawancarai terlebih dahulu dan ketika konsumen selesai menjawab semua pertanyaan kuisioner barulah selanjutnya mewawancarai responden yang lainnya.

\section{Desain dan Metode Penelitian}

Penelitian ini berparadigma positivism. Metode penelitian dilakukan secara deskriptif kuantitatif.Adapun gambaran data kuantitatif yang ingin didapatkan pada penelitian ini adalah karakteristik responden (ibu-ibu rumah tangga yang membeli produk sayuran organik di pasar modern Kota Pekanbaru), dan jenis komoditi yang paling diinginkan oleh responden.

Sementara itu, analisis faktor dan analisis jalur digunakan untuk kelengkapan metode deskripsi pada penelitian ini. Hair Jr., dkk dalam Aritonang (2005) menambahkan bahwa khususnya mengenai analisis faktor maupun jalur lebih disukai 100 subyek atau lebih, maka untuk penelitian ini ada lebih kurang 103 responden untuk 3 pasar modern sehingga didapat 310 responden untuk diwawancarai. Sementara itu, untuk analisis jalur, tataran data variabel penelitian yang dikumpulkan berbentuk skor data rentang (interval) atau menggunakan skala interval yaitu rentang 1-5.

\section{HASIL DAN PEMBAHASAN Gambaran Wilayah Penelitian}

Kecamatan Tampan terletak didalam wilayah Kota Pekanbaru, Riau. Kota Pekanbaru merupakan ibukota Propinsi Riau. Keberadaan Kota Pekanbaru merupakan dasar dekonsentrasi sebagaimana dimaksud dalam Perda Kota Pekanbaru No. 3 Tahun 2003, Kota Pekanbaru dibagi atas 12 (dua belas) Kecamatan yang terdiri dari 58 Kelurahan, RW sebanyak 617 dan RT sebanyak 2.643 khusus Kecamatan Tampan terdiri atas 4 kelurahan, $71 \mathrm{RW}$ dan 424 RT. Luas wilayah Kec. Tampan 59,81 Km², dengan luas Kelurahan Simpang Baru: 23,59 Km², Kelurahan Sidomulyo Barat: 13,69 Km², Kelurahan Tuah Karya: 12,09 $\mathrm{Km}^{2}$, Kelurahan Delima: 10,44 Km². Batas wilayah Kecamatan Tampan untuk sebelah timur dengan Kecamatan Marpoyan Damai, sebelah barat berbatasan dengan Kabupaten Kampar, sebelah utara berbatasan dengan Kecamatan Payung Sekaki dan sebelah 
selatan berbatasan dengan Kabupaten Kampar. Adapun pusat kecamatan berada di Simpang Baru.

Adapun jumlah penduduk Kec. Tampan Tahun 2013 adalah: 206.267 jiwa (laki-laki sebanyak 105.650 jiwa dan perempuan 100.617 jiwa) dan mengalami peningkatan $7,2 \%$ dari tahun 2012, kepadatan penduduknya mencapai 3.442 jiwa/ $\mathrm{Km}^{2}$ dengan kelurahan terpadat adalah Tuah Karya sebesar 6.398 jiwa/ $/ \mathrm{Km}^{2}$. Sementara itu data penduduk menurut kelompok umur dengan penduduk terbanyak pada Kelurahan Tuah Karya dengan jumlah 77.353 jiwa dan memiliki kelompok umur besar dari 24 tahun sebanyak 27.750 jiwa. Selanjutnya berturut-turut diikuti data penduduk Sidomulyo Barat yaitu 20.752 jiwa, Simpang Baru sebanyak 16.746 dan Delima: 15.069 jiwa. Kelurahan Delima memiliki data penduduk terendah dibanding kelurahan lainnya yaitu:
34.830 jiwa. Selanjutnya, jumlah penduduk 15 tahun keatas di Kelurahan Tuah Karya yang bekerja sebanyak 15.794 jiwa, mencari pekerjaan: 8.696 jiwa, sekolah: 14.787 jiwa dan aktivitas lainnya: 9.261 jiwa masing-masing data tersebut merupakan jumlah yang tertinggi dibanding kelurahan lainnya yaitu: Sidomulyo Barat, Simpang Baru dan Delima. Sementara itu, Kelurahan Delima memiliki penduduk 15 tahun keatas lebih rendah yaitu 23.183 jiwa dengan rincian 8.887 jiwa yang bekerja, mencari pekerjaan 3.371 jiwa, sekolah 6.571 jiwa dan aktivitas lainnya 4.354 jiwa. Menurut Van den ban dan Hakwkins (1999), usia tenaga kerja yang produktif berumur 16-64 tahun, sedangkan pada usia 65 keatas sudah dikatakan usia lanjut.

Dilain hal,data luas tanam dan produksi sayur-sayuran menurut jenis sayuran di Kec. Tampan pada tahun 2013 dapat dilihat pada Tabel 1.

Tabel 1. Luas Tanam dan Produksi Sayur-sayuran Menurut Jenis Sayuran di Kecamatan Tampan Tahun 2013.

\begin{tabular}{llcc}
\hline & Jenis Sayuran & Luas Tanam $(\mathrm{Ha})$ & Produksi (Ton) \\
\hline 1. & Timun & 31 & 372 \\
2. & Terong & 29 & 420 \\
3. & Kacang Panjang & 57 & 969 \\
4. & Bayam & 112 & 1120 \\
5. & Kangkung & 112 & 1120 \\
6. & Cabe & 59 & 295 \\
7. & Petsai & 46 & 690 \\
8. & Pare & 12 & 120 \\
\hline
\end{tabular}

Sumber : BPS Kota Pekanbaru (2013). 
Elfi Rahmadani dan Penti Suryani: Analisis Nilai dan Pengetahuan Ibu-ibu Rumah Tangga sebagai Prediktor Intensi Beli Produk Sayuran Organik di Pasar Modern Kota Pekanbaru

Pada Tabel 1 terlihat bayam dan kangkung merupakan sayuran yang banyak dibudidayakan di Kecamatan Tampan yang mana memiliki luas tanam 112 ha dan produksi 1120 ton. Luas tanam dan produksi bayam dan kangkung di kecamatan ini menunjukkan nilai tertinggi dari komoditi sayuran lainnya seperti cabe, kacang panjang, petsai, mentimun, terong dan pare. Dari Tabel 1 juga memperlihatkan sayuran dengan komoditi pare memiliki luas tanam dan produksi yang terendah dari komoditi pertanian lainnya. Dimana pare memiliki luas tanam 12 ha dan produksi 120 ton.

\section{Kecamatan Payung Sekaki}

Kecamatan Payung Sekaki terdiri atas 39 RW dan 181 RT. Luas wilayah Kec. Payung Sekaki 51,36 Km², dengan luas Kelurahan Labuh Baru Timur: 11,80
$\mathrm{Km}^{2}$, Kelurahan Tampan: 10,00 Km², Kelurahan Air Hitam: 5,46 Km², Kelurahan Labuh Baru Barat: 24,10 Km². Batas wilayah Kecamatan Payung Sekaki untuk sebelah timur dengan Kecamatan Sukajadi dan Senapelan, sebelah barat berbatasan dengan Kabupaten Kampar, sebelah utara berbatasan dengan Kecamatan Rumbai dan sebelah selatan berbatasan dengan Kecamatan Tampan dan Kecamatan Marpoyan Damai. Adapun pusat kecamatan berada di Kelurahan Labuh Baru Barat.

Adapun jumlah penduduk Kec. Payung Sekaki Tahun 2013 adalah: 78.550 jiwa (laki-laki sebanyak 37.987 jiwa dan perempuan 40.563 jiwa) dan kelurahan terpadat adalah Labuh Baru Timur sebesar 24.994 jiwa/ $\mathrm{Km}^{2}$. Sementara itu data penduduk menurut kelompok umur dapat dilihat pada Tabel 2.

Tabel 2. Data Penduduk Menurut Jenis Kelamin (Jiwa) Pada Kelurahan di Kecamatan Payung Sekaki.

\begin{tabular}{lccc}
\hline \multirow{2}{*}{ Kelurahan } & \multicolumn{2}{c}{ Jenis Kelamin } & \multirow{2}{*}{ Jumlah } \\
\cline { 2 - 3 } & Laki-laki & Perempuan & \\
\hline Labuh Baru Timur & 11.798 & 13.196 & 24.994 \\
Tampan & 10.173 & 10.805 & 20.978 \\
Air Hitam & 3.798 & 4.133 & 7.931 \\
Labuh Baru Barat & 12.218 & 12.429 & 24.647 \\
\hline Jumlah & 37.978 & 40.563 & 78.550 \\
\hline
\end{tabular}

Sumber: BPS Kota Pekanbaru (2013). 
Dari Tabel 2 terlihat bahwa jumlah penduduk dengan jenis kelamin laki-laki banyak terdapat pada Kelurahan Labuh Baru Barat dengan jumlah 12.218jiwa danjumlah penduduk jenis kelamin perempuan banyak terdapat di Kelurahan Labuh Baru Timur yaitu 13.196 jiwa. Kelurahan Air Hitam memiliki jumlah penduduk terendah baik untukjenis kelamin perempuan dan laki-laki dibanding kelurahan lainnya yaitu: 7.931 jiwa.Sementara itu, jumlah penduduk menurut kelompok umur di Kecamatan Payung Sekaki dengan jumlah terbanyak berada pada kisaran umur 16 -18 tahun yaitu 25.931 jiwa, sedangkan penduduk dengan usia 1924 tahun memiliki jumlah terkecil yaitu 8.977 jiwa. Menurut Bappenas (2014), di dalam analisis demografi, struktur umur penduduk dibedakan menjadi tiga kelompok, yaitu (a) kelompok umur muda, dibawah 15 tahun; (b) kelompok umur produktif, usia 15 - 64 tahun; dan (c) kelompok umur tua, usia 65 tahun ke atas.

Dilain hal, data luas tanam dan produksi sayur-sayuran menurut jenis sayuran di Kec. Payung Sekaki pada tahun 2013 dapat dilihat pada Tabel 3.

Tabel 3. Luas Tanam dan Produksi Sayur-sayuran Menurut Jenis Sayuran di Kecamatan Tampan Tahun 2013.

\begin{tabular}{llc}
\hline & Jenis Sayuran & Produksi (Ton) \\
\hline 1. & Timun & 36 \\
2. & Terong & 60 \\
3. & Kacang Panjang & 119 \\
4. & Kangkung & 40 \\
5. & Cabe & 45 \\
\hline
\end{tabular}

Sumber: BPS Kota Pekanbaru (2013).

Jika diperhatikan pada Tabel 3 terlihat kacang panjang merupakan sayuran yang banyak dibudidayakan di Kecamatan Payung Sekaki dengan produksi 119 ton sedangkan untuk produksi terendah terdapat pada komoditi timun yaitu 36 ton.

\section{Karakteristik Responden dan Analisis Faktor Karakteristik Responden}

Berdasarkan analisis data hasil penelitian, maka didapatkan responden yang berusia 17-27 tahun berjumlah 36 orang atau sebesar $11,61 \%$, responden yang berusia 28-38 tahun sebanyak 134 responden atau sebesar 43,23\% yang berusia 39-49 tahun berjumlah 110 orang atau sebesar $35,48 \%$, dan yang berusia 50-60 tahun berjumlah 30 orang atau sebesar $9,68 \%$. Selanjutnya tingkat pendidikan responden tertinggi 
Elfi Rahmadani dan Penti Suryani: Analisis Nilai dan Pengetahuan Ibu-ibu Rumah Tangga sebagai Prediktor Intensi Beli Produk Sayuran Organik di Pasar Modern Kota Pekanbaru

berpendidikan SMP sebanyak 133 orang $(42,90 \%)$, berdasarkan data pekerjaan dapat diidentifikasi bahwa mayoritas responden memiliki pekerjaan ibu rumah tangga yaitu sebanyak 154 responden atau sebesar $49,68 \%$, responden yang memiliki pekerjaan pegawai swasta sebanyak 37 responden atau sebesar $11,94 \%$, responden yang memiliki pekerjaan wiraswasta sebanyak 26 responden atau sebesar $8,39 \%$ dan responden yang memiliki pekerjaan PNS sebanyak 93 responden atau sebesar $30 \%$. Selanjutnya untuk tanggungan keluarga berjumlah 3-4 orang memiliki persentase tertinggi dari yang lainnya yaitu $54,84 \%$ atau 170 responden dan tanggungan keluarga yang berjumlah 7-8 orang memiliki persentase $5,16 \%$ atau 16 orang.

Dilain hal, frekuensi sayuran yang dikonsumsi oleh responden penelitian adalah $41,94 \%$ (2-3 kali dalam seminggu),32,26\% mengkonsumsi sekali seminggu, 16,13\% mengkonsumsi setiap hari dan 9,68 \% menyatakan tidak mengkonsumsi sayuran dalam seminggu. Data ini memperlihatkan keprihatinan terhadap gizi masyarakat yang masih rendah dari anjuran lembaga $\mathrm{PBB}$ (WHO atau World Health Organization) yang mewajibkan mengkonsumsi sayur $400 \mathrm{~g}$ per- hari. Pada penelitian ini juga memberikan hasil bahwa pengetahuan responden mengenai sayuran organik memiliki keterbatasan karena sumber informasi yang mereka gunakan hanya dari tetangga dan media televisi (99\%) dan media lain $(0,007 \%)$ sehingga responden tidak memiliki pengetahuan yang lengkap (tinggi) mengenai sayuran organik. Sikap responden pada sayuran organik juga terbatasi dengan harga sayuran organik di pasaran yang tergolong tinggi, jarang tersedia di pasar tradisional dan hanya tersedia dipasarpasar tertentu sehingga belum terjangkau oleh kebanyakan responden. Sedangkan responden pada pembudidayaan sayuran organik terbatasi karena kepemilikan rumah yang sewa/kontrak dengan kondisi lingkungan rumah mereka yang saling berdempetan sehingga tidak ada ruang. Sementara itu, pengeluaran tertinggi yang mereka keluarkan untuk kebutuhan konsumsi pangan keluarga tertinggi pada Rp 25.000,-30.000,-- per-hari. Hal inikarenamerekamempertimbangkan jumlah keluarga dan pengeluaran untuk pembayaran rumahyang mereka tempati. (64,52 \% atau 200 reponden memiliki tempat tinggal sewa).

\section{Analisis Faktor}

Berdasarkan analisis faktor yang sudah dilakukan didapatkan angka KMO Measure of Sampling Adequacy sebesar 0,566 dengan signifikansi sebesar 0,000. Angka 0,566 berada diatas angka 0,5 dan signifikansi 0,00 lebih kecil dari 0,05 maka variable dan data diatas dapat terus dianalisis lebih lanjut. Lebih jelas dapat dilihat pada Tabel 4. Anti-image Matrices. 
Tabel 4. Anti-Image Matrice

Anti-image Matrices

\begin{tabular}{|c|c|c|c|c|c|c|c|}
\hline & & $\begin{array}{l}\text { pengeluaran } \\
\text { untuk } \\
\text { membelisayur } \\
\text { (X1) }\end{array}$ & $\begin{array}{l}\text { Usia } \\
(\mathrm{X} 2)\end{array}$ & $\begin{array}{l}\text { Juml.anggota } \\
\text { keluarga (X3) }\end{array}$ & $\begin{array}{c}\text { Tingkat } \\
\text { Pendidikan } \\
\text { (D1) }\end{array}$ & $\begin{array}{l}\text { Banyaknya } \\
\text { jumlah } \\
\text { konsumsi } \\
\text { sayur (D2) }\end{array}$ & $\begin{array}{l}\text { Kepemilika } \\
\text { n rumah } \\
\text { (D3) }\end{array}$ \\
\hline \multirow[t]{6}{*}{$\begin{array}{l}\text { Anti-image } \\
\text { Correlation }\end{array}$} & $\begin{array}{l}\text { Pengeluaran } \\
\text { un tuk } \\
\text { membeli sayur } \\
(\mathrm{X} 1)\end{array}$ & $.616^{\mathrm{a}}$ & -.110 & -.174 & .033. & -.016 & -.046 \\
\hline & Usia (X2) & -.110 & $.598^{a}$ & -.096 & -.130 & -.007 & -.124 \\
\hline & $\begin{array}{l}\text { Juml.anggota } \\
\text { keluarga (X3) }\end{array}$ & -.174 & -.096 & $.563^{a}$ & .091 & -.066 & -.197 \\
\hline & $\begin{array}{l}\text { Tingkat } \\
\text { Pendidikan } \\
\text { (D1) }\end{array}$ & .033. & -.130 & .091 & $.441^{\mathrm{a}}$ & -.042 & -.044 \\
\hline & $\begin{array}{l}\text { Banyaknya } \\
\text { jumlah } \\
\text { konsumsi } \\
\text { sayur (D2) }\end{array}$ & -.016 & -.007 & -.066 & -.042 & $.399^{a}$ & .098 \\
\hline & $\begin{array}{l}\text { Kepemilikan } \\
\text { rumah (D3) }\end{array}$ & -.046 & -.124 & -.197 & -.044 & .098 & $.576^{\mathrm{a}}$ \\
\hline
\end{tabular}

a. Measures of Sampling Adequacy(MSA)

Tidak semua variabel pengukuran mempunyai nilai anti image korelasi $>0,5$ yang berarti bahwa tidak semua sub-variabel pengukuran atau dimensi berhak dijadikan komponen faktor bersama penentu intensi beli ibu rumah tangga terhadap sayur organik terutama tingkat pendidikan yang memiliki nilai anti image korelasi 0,441 dan variabel jumlah/banyaknya konsumsi sayur perminggu 0,399.
Gusrini ${ }^{14}$ menyatakan bahwa tingkat pendidikan sangat diperlukan oleh karena akan dapat membawa pengaruh yang baik terhadap dirinya sendiri maupun terhadap tempat dia bekerja. Tingkat pendidikan juga akan berpengaruh kuat terhadap pengetahuan dan keterampilan orang tersebut dalam mengkonsumsi sayur. Sementara itu, pada Tabel 5. terlihat peranan dimensi yang terbesar dalam intensi daya beli ibu rumah tangga terhadap sayur organik adalah subvariabel banyaknya konsumsi sayur sebesar 0,843 atau 84,3\% dan yang 
Elfi Rahmadani dan Penti Suryani: Analisis Nilai dan Pengetahuan Ibu-ibu Rumah Tangga sebagai Prediktor Intensi Beli Produk Sayuran Organik di Pasar Modern Kota Pekanbaru

terkecil adalah biaya yang dikeluarkan untuk membeli sayur sebesar 0,424 atau $42,4 \%$. Hal ini sesuai dengan pernyataan Peter dan Olson (2005) yang menjelaskan bahwa perilaku seseorang seperti dalam membeli sayur organik akan melibatkan pemikiran dan perasaan, pengalaman seseorang dan tingkah laku yang mereka tunjukkan dalam proses konsumsi.

Tabel 5.Dimensi Intensi Beli Sayuran Organik Oleh Ibu Rumah Tangga

\begin{tabular}{lcc}
\hline & Communalities & \\
\hline & Initial & Extraction \\
\hline Pengeluaran untuk membeli sayur(X1) & 1.000 & .424 \\
Usia (X2) & 1.000 & .514 \\
Juml.anggota kluarga (X3) & 1.000 & .569 \\
Tingkat Pendidikan (D1) & 1.000 & .762 \\
banyak konsumsi sayur (D2) & 1.000 & .843 \\
kepemilikan rumah (D3) & 1.000 & .524 \\
\hline
\end{tabular}

Extraction Method: Principal Component Analysis.

Dari enam variabel pengukuran atau dimensi (X1 sd D3) terbentuk tiga faktor bersama, yaitu faktor bersama satu (F1) dengan persentase variansnya $=24,788$ dan faktor bersama dua (F2) dengan persentase varians $=18,33$ dan faktor bersama tiga (F3) dengan persentase variansnya $=17,461$ serta kumulatif persentase varians yang terbentuk dari ketiga faktor bersama adalah sebesar $=60,579$ dan sisanya $39,421 \%$ terdiri atas tiga faktor bersama. Jadi jumlah faktor bersama yang mewakilienam sub-variabel pengukuran atau dimensi (X1 sd D3) ditentukan oleh nilai initial eigenvalue total yang $\mathrm{e}^{\prime \prime} 1$ yaitu sebanyak tiga faktor yaitu F1, F2 dan F3. Dari3 faktor diperolehkomponen matrik yaitu:

1. Variabel biaya pengeluaran untuk sayur memiliki nilai pada faktor 1 yaitu 0,571 dan faktor $2=-0.224$ dan faktor $3=0,218$, karena nilai tertinggi variabel ini terdapat pada faktor1 maka variabel biaya pengeluaran untuk sayur termasuk kelompok faktor 1 yang perlu dipertimbangkan

2. Variabel usia pembeli sayur memiliki nilai pada faktor 1 yaitu 0,573 dan faktor $2=0,430$ dan faktor $3=0,021$, karena nilai tertinggi variabel ini terdapat pada faktor1 maka variabel usia termasuk kelompok faktor 1.

3. Pada variabel jumlah anggota keluarga pembeli sayur memiliki 
nilai pada faktor 1 yaitu 0,671 dan faktor $2=-0,315$ dan faktor $3=0,138$, karena nilai tertinggi variabel ini terdapat pada faktor1 maka variabel anggota keluarga termasuk kelompok faktor 1 .

4. Pada variabel tingkat pendidikan pembeli sayur memiliki nilai pada faktor 1 yaitu 0,061 dan faktor $2=$ 0,869 dan faktor $3=0,046$, karena nilai tertinggi variabel ini terdapat pada faktor2 maka variabel termasuk tingkat pendidikan termasuk kelompok faktor 2.

5. Pada variabel banyaknya konsumsi sayur memiliki nilai pada faktor 1 yaitu 0,000 dan faktor $2=0,074$ dan faktor $3=0,915$, karena nilai tertinggi variabel ini terdapat pada faktor3 maka variabel banyaknya konsumsi sayur termasuk termasuk kelompok faktor 3.

6. Variabel kepemilikan rumah memiliki nilai pada faktor 1 yaitu 0,615 dan faktor $2=0,064$ dan faktor $3=-0,376$, karena nilai tertinggi variabel ini terdapat pada faktor1 maka variabel kepemilikan rumah termasuk kelompok faktor 1.

Penjelasan tersebut menunjukkan bahwa perilaku kelompok sosial masyarakat dalam membeli suatu produk tidak hanya ditentukan oleh satu faktor saja seperti: biaya pengeluaran untuk membeli sayur, usia, jumlah anggota keluarga, dan kepemilikan rumah tapi juga tingkat pendidikan, dan variabel banyaknya konsumsi sayur. Untuk Faktor 1 menempatkan biaya pengeluaran, usia pembeli, jumlah anggota keluarga dan kepemilikan rumah. Dalam hal ini, mereka menempatkan banyaknya konsumsi sayur pada faktor ke-3 karena bagi mereka kebutuhan jumlah anggota keluarga harus tercukupi dulu begitupula dengan pengeluaran untuk biaya rumah mereka yang kebanyakan bukan milik sendiri tapi sewa. Sementara itu, faktor pendidikan juga merupakan faktor yang kedua penting setelah semua pengeluaran terakomodir pada faktor 1. Dari komponen matrik maka dapat dilihat rumus komponen score dari koefisien matrik maka dapat dilihat pada Tabel 6 . 
Elfi Rahmadani dan Penti Suryani: Analisis Nilai dan Pengetahuan Ibu-ibu Rumah Tangga sebagai Prediktor Intensi Beli Produk Sayuran Organik di Pasar Modern Kota Pekanbaru

Tabel 6.Component Score Coefficient Matrix

\begin{tabular}{lccc}
\hline & \multicolumn{3}{c}{ Component } \\
\hline pengeluaran tuk sayur (X1) & 1 & 2 & 3 \\
Usia (X2) & .384 & -.204 & .208 \\
Juml.anggota kluarga (X3) & .385 & .391 & .020 \\
Tingkat Pendidikan (D1) & .451 & -.286 & .132 \\
banyak konsumsi sayur(D2) & .041 & .791 & .044 \\
kepemilikan rumah (D3) & .000 & .067 & .873 \\
\hline
\end{tabular}

Extraction Method: Principal Component Analysis.

Component Scores.

Dari Tabel 6 diatas didapat persamaan faktor sebagai berikut: untuk skor faktor satu -> F1 = 0,384 ZX1 + 0,385 ZX2 + 0,451 ZX3 + 0,041 ZD1 +0ZD2 + 0,413 ZD3.Untuk skor faktor dua -> F2

$=-0,204$ ZX1 + 0,391 ZX2 - 0,286 ZX3
$+0,791$ ZD1 +0,067 ZD2 + 0,058
ZD3.Untuk skor faktor tiga -> F3= 0,208
ZX1 + 0,020 ZX2 + 0,132 ZX3 +0,044 ZD1
+ 0,873 ZD2 - 0,359 ZD3.
Analisis
(Analisisxxxeliabilitas variable
penelitian dapat dilihat pada Tabel7.

Tabel 7. Hasil Uji Validitas Kuisioner

\begin{tabular}{l|c|c|c}
\hline Kategori & Pernyataan & Nilai Validitas & Keterangan \\
\hline \multirow{2}{*}{$\begin{array}{l}\text { Intensi Beli Sayuran } \\
\text { Organik }\end{array}$} & 1 & 0.336 & Valid \\
\cline { 2 - 4 } & 2 & 0.666 & Valid \\
\cline { 2 - 4 } & 3 & 0.647 & Valid \\
\hline \multirow{2}{*}{\begin{tabular}{l} 
Sikap terhadap Sayuran \\
\cline { 2 - 4 }
\end{tabular}} & 1 & 0.695 & Valid \\
\cline { 2 - 4 } & 2 & 0.665 & Valid \\
\cline { 2 - 4 } & 3 & 0.541 & Valid \\
\hline \multirow{2}{*}{$\begin{array}{l}\text { Nilai Orientasi Alami } \\
\text { Manusia terhadap }\end{array}$} & 1 & 0.730 & Valid \\
\cline { 2 - 4 } & 2 & 0.589 & Valid \\
\cline { 2 - 4 } & 3 & 0.700 & Valid \\
\hline Penuran Organik & 4 & 0.571 & Valid \\
\cline { 2 - 4 } & 2 & 0.651 & Valid \\
\cline { 2 - 4 } & 3 & 0.434 & Valid \\
\cline { 2 - 4 } & 4 & 0.562 & Valid \\
\hline
\end{tabular}

Keterangan: Data Olahan (2014) 
Tabel 7 menunjukkan bahwa butir pernyataan yang digunakan dalam kuesioner penelitian ini seluruhnya valid karena memiliki nilai hitung korelasi $(r$ hitung) $>0.113$, sehingga 15 pernyataan dapat diterima dan diikutsertakan dalam pengolahan berikutnya.

Tabel 8. Hasil Uji Reliabilitas Kuisioner

\begin{tabular}{l|c|c|c}
\hline \multicolumn{1}{c|}{ Kategori } & Nilai Alpha Cronbach & Jumlah Item & Keterangan \\
\hline Intensi Beli Sayuran Organik & 0,876 & 3 & Reliabel \\
\hline $\begin{array}{l}\text { Sikap terhadap Sayuran } \\
\text { Organik }\end{array}$ & 0,638 & 4 & Reliabel \\
\hline $\begin{array}{l}\text { Nilai Orientasi Alami } \\
\text { Manusia terhadap Sayuran } \\
\text { Organik }\end{array}$ & 0,667 & 4 & Reliabel \\
\hline $\begin{array}{l}\text { Pengetahuan terhadap } \\
\text { Sayuran Organik }\end{array}$ & 0,744 & 4 & Reliabel \\
\hline
\end{tabular}

Tabel 8 menunjukkan bahwa butir pernyataan yang mewakili variabel dalam kuesioner penelitian ini seluruhnya memiliki reliabilitas kuesioner yang reliabel karena memiliki nilai $r$ hitung > 0,113 dan masing-masing faktor memiliki Alpha lebih besar dari 0,6. Menurut Nunnally (1981), nilai koefisien reliabilitas yang dianjurkan minimal 0,6.Instrumen sudah baik, valid dan reliabel.

\section{Uji Hipotesis}

Hasil uji kausalitas model dalam penelitian ini secara lengkap seperti pada Gambar 1. Hasil bobot regresi antar variabel laten yang sering disebut sebagai estimasi loading factors atau lambda value dapat digunakan untuk menganalisis uji kausalitas variabel. Berdasarkan signifikansi nilai CR (Critical Ratio) dengan nilai probabilitas $(p)=0.05$. Hasil bobot regresi uji kausalitas seperti pada Tabel 9.

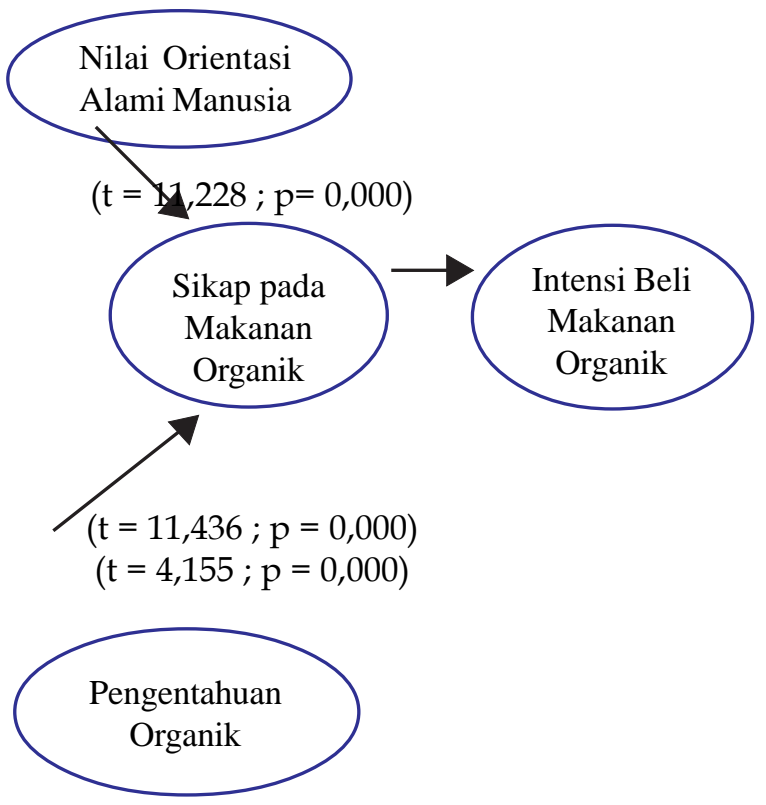

Gambar 1. Model Jalur 
Elfi Rahmadani dan Penti Suryani: Analisis Nilai dan Pengetahuan Ibu-ibu Rumah Tangga sebagai Prediktor Intensi Beli Produk Sayuran Organik di Pasar Modern Kota Pekanbaru

Tabel 9. Evaluasi Bobot Regresi Uji Kausalitas

\begin{tabular}{cccc}
\hline Hipotesis & Variabel & CR & $\mathrm{p}$ \\
\hline Hipotesis 1 & OAM $\rightarrow$ SB & 11,228 & 0,000 \\
Hipotesis 2 & PO $\rightarrow$ SB & 4,155 & 0,000 \\
Hipotesis 3 & SB $\rightarrow$ IB & 11,436 & 0,000 \\
\hline
\end{tabular}

Keterangan :

$\begin{array}{ll}\text { OAM } & =\text { Nilai Orientasi Alami Manusia } \\ \text { PO } & =\text { Pengetahuan Organik } \\ \text { SB } & =\text { Sikap pada Sayuran Organik } \\ \text { IB } & =\text { Intensi Beli }\end{array}$

Penjelasan lebih lanjut analisis evaluasi bobot regresi tersebut dapat dijelaskan bahwa variabel bilai orientasi alami manusia mempengaruhi sikap ibu-ibu rumah tangga pada sayuran organik secara positif dan signifikan dengan tingkat signifikansi sebesar 0,000 lebih kecil dari nilai probabilitas d" 0,05. Dengan demikian hipotesis 1 diterima. Variabel pengetahuan organik mempengaruhi sikap ibu-ibu rumah tangga pada sayuran organik secara positif dan signifikan dengan tingkat signifikansi sebesar 0,000 lebih kecil dari nilai probabilitas d" 0,05. Dengan demikian hipotesis 2 diterima.
Variabel sikap pada makanan organik mempengaruhi intensi beli makanan organik secara positif dan signifikan dengan tingkat signifikansi sebesar 0,000 lebih kecil dari nilai probabilitas d" 0,05. Dengan demikian hipotesis 3 diterima. Berdasarkan nilai koefisien terstandar dapat diketahui bahwa sikap ibu-ibu rumah tangga terhadap sayuran organik dominan mempengaruhi intensi beli sayuran organik dibandingkan nilai orientasi alami manusia. Besarnya kontribusi variabel secara simultan terhadap variabel lainnya diringkas dalam Tabel 10.

Tabel 10. Koefisien Determinasi

\begin{tabular}{lcc}
\hline \multicolumn{1}{c}{ Variabel yang Mempengaruhi } & Variabel yang Dipengaruhi & Sumbangan Efektif \\
\hline Sikap terhadap sayuran organik & Intensi beli sayuran organic & $29,8 \%$ \\
Nilai orientasi alami manusia & Sikap pada sayuran organic & $29,0 \%$ \\
Pengetahuan organic & Sikap pada sayuran organic & $5,3 \%$ \\
\hline
\end{tabular}


Berdasarkan Tabel 10 di atas dapat diketahui bahwa variabel sikap terhadap sayuran organik memiliki peran sebesar $29,8 \%$ terhadap intensi beli sayuran organik. Variabel nilai orientasi alami manusia memiliki peran sebesar 29,0\% terhadap sikap pada sayuran organik, sedangkan variabel pengetahuan organik hanya berperan $5,3 \%$ terhadap sikap pada sayuran organik.

\section{Hipotesis yang Berkaitan dengan Nilai Orientasi Alami Manusia}

Hasil hipotesis mengenai pengaruh nilai orientasi alami manusia mendukung hipotesis 1 diterima. Hasil temuan menunjukkan nilai orientasi alami ibu-ibu rumah tangga berpengaruh positif dan signifikan terhadap sikap ibu-ibu rumah tangga di Kota Pekanbaru pada sayuran organik. Hasil temuan penelitian ini konsisten dengan hasil temuan Dreezens et al. (2005); Krystallis et al. (2008); Padel \& Foster (2005); Chen \& Chai (2010) dan Wijaya \& Hidayat (2011). Hasil temuan menunjukkan semakin tinggi nilai orientasi alami manusia pada ibu-ibu rumah tangga di Kota Pekanbaru maka semakin baik sikap pada sayuran organik, sebaliknya semakin rendah nilai orientasi alami pada ibu-ibu rumah tangga di Kota Pekanbaru maka semakin burukjuga sikap pada sayuran organik.

Sayuran organik sebagai produk ramah lingkungan merupakan elemen sistem keyakinan individu.Secara spesifik, Arnould etal. (2004) menjelaskan hubungan nilai dengan perilaku konsumen melalui mekanisme secara hierarkhi. Nilai berperan dalam membentuk sikap konsumen.Nilai merupakan pertimbangan yang fundamental bagi hubungan konsumen dengan lingkungan.Penduduk Asia memandang diri mereka sebagai bagian dari alam dan hidup harmonis dengan alam atau berorientasi pada alam yang disebut Chan (2001) sebagai orientasi alami manusia (Man Nature Orientation). Konsumen yang memiliki orientasi alami manusia cenderung mempertimbangkan akibat-akibat konsumsi pada lingkungan sehingga memiliki sikap ramah lingkungan(Chan, 2001) dan mendukung penggunaan produk organik (Wijaya \& Hidayat, 2011).

Filosofi nilai Negara Timur berbeda dengan nilai di Negara Barat.Sebagai contoh yang berkaitan dengan alam, nilai-nilai inti yang diabut oleh masyarakat Amerika adalah menaklukkan alam (Engel et al., 2005), berbeda dengan Asia yang cenderung mengutamakan keseimbangan alam (Chan, 2001). Amerika memiliki nilai menaklukkan alam, contohnya seperti menghadapi perubahan alam dan hama dengan bahan kimia, selain itu nilai menaklukkan alam juga ditunjukkan dengan iklan-iklan komersial yang ada (Engel et al., 2005).

Masyarakat Indonesia yang 
Elfi Rahmadani dan Penti Suryani: Analisis Nilai dan Pengetahuan Ibu-ibu Rumah Tangga sebagai Prediktor Intensi Beli Produk Sayuran Organik di Pasar Modern Kota Pekanbaru

menjelaskan bahwa masyarakat yang cendrung kolektivis yang ditunjukkan dengan pembangunan agraris, budaya tradisional, nilai-nilai gotong royong, hidup selaras dengan alam yang dicerminkan lewat acara-acara tradisi seperti slametan, tradisi di gunung merapi dan laut selatan, mengutamakan harmoni dibandingkan ambisi pribadi.

\section{Hipotesis yang berkaitan dengan} Pengetahuan Organik

Hasil penelitian menemukan adanya pengaruh pengetahuan organik secara positif dan signifikan terhadap sikap ibu-ibu rumah tangga di Kota Pekanbaru pada sayuran organik.Hasil hipotesis mengenai pengaruh pengetahuan organik mendukung hipotesis 2 diterima.Hasil temuan ini konsisten dengan temuan Amyx et al. (1994); Chan (1999); Junaedi (2007); dan Magistris \& Gracia (2008). Hasil ini menunjukkan semakin tinggi tingkat pengetahuan organik dari ibu-ibu Rumah Tangga di Kota Pekanbaru maka semakin baik sikap pada makanan organik, sebaliknya semakin rendah tingkat pengetahuan organik dari ibuibu rumah tangga maka semakin buruk sikap pada sayuran organik.

Sikap merupakan susunan dari keyakinan dan evaluasi terhadap perilaku. Keyakinan dan evaluasi konsumen didasarkan pada berbagai pertimbangan melalui pengetahuan yang dimiliki konsumen. Konsumen yang memiliki pengetahuan organik cendrung memiliki sikap positif terhadap sayuran organik karena yakin sayuran organik bermanfaat bagi konsumen. Konsumen juga yakin dengan mengkonsumsi makanan organik, konsumen akan memperoleh manfaat seperti kesehatan, kealamian dan keamanan konsumsi yang dikandung dalam makanan organik. Magistris \& Gracia (2008) juga menjelaskan bahwa pengetahuan mewakili kemampuan konsumen dalam membedakan produk organik atau non organik serta membentuk sikap positif pada produk organik.Keyakinan terhadap peran hidup sehat merupakan determinan dalam penerimaan pangan

Konsumen membeli produkproduk organik karena memiliki pengetahuan mengenai dampak konsumsi produk pada konsumen dan lingkungan (Chan, 2001). Kurangnya pengetahuan konsumen tentang kandungan dalam pangan fungsional akan menghambat proses keyakinan konsumen. Hal lain yang bersifat internal dalam membentuk sikap individu untuk berperilaku adalah ketersediaan informasi, keterampilan dan kemampuan yang memperkuat motivasi individu. Sikap cenderung berubah sesuai perubahan tingkatpengetahuan(Aertsens et al., 2009). Pengetahuan organik menyediakan informasi mengenai makanan organic dan manfaatnya sehingga memperkuat motivasi individu 
dalam mempertimbangkan pembelian makanan organic.

\section{Hipotesis yang berkaitan dengan Sikap pada Makanan Organik}

Hasil temuan membuktikan bahwa adanya pengaruh sikap ibu-ibu rumah tangga di Kota Pekanbaru pada makanan organik secara positif dan signifikan terhadap intensi beli makanan organik.Temuan tersebut mendukung hipotesis 3 yang diajukan dalam penelitian.Sikap pada makanan organik berpengaruh signifikan terhadap intensi beli makanan organik. Hasil temuan konsisten dengan hasil temuan Chan (1999); Chan \& Lau (2000); Wijaya \& Hidayat (2011); Kalafatis et.al (1999); Chiou, (1998); dan Aertsens et al. (2009). Hasil temuan menjelaskan bahwa semakin kuat sikap pada sayuran organik maka semakin tinggi intensi beli ibu-ibu rumah tangga di Kota Pekanbaru, sebaliknya semakin lemah sikap pada sayuran organik maka semakin rendah juga intensi beli ibu-ibu rumah tangga di Kota Pekanbaru.

Sesuai konsep dasar teori perilaku terencana menunjukkan bahwa sikap merupakan prediktor yang baik bagi intensi berperilaku. Teori perilaku terencana menyebutkan bahwa intensi adalah fungsi dari determinan sikap terhadap perilaku, yang merupakan dasar bagi pembentukan intensi. Menurut Ajzen (1991) terwujud tidaknya intensi sangat tergantung pada faktor eksternal dan internal. Faktor internal tergantung pada keyakinan dari individu dalam berperilaku dan dapat tidaknya berperilaku sedangkan faktor eksternal merupakan stimulus yang mendorong individu untuk berperilaku.

Semakin positif keyakinan individu akan akibat dari suatu obyek sikap, maka akan semakin positif pula sikap individu terhadap obyek sikap tersebut, demikian pula sebaliknya (Fishbein \& Ajzen, 1975). Evaluasi akan berakibat perilaku penilaian yang diberikan individu terhadap tiap-tiap akibat atau hasil yang diperoleh oleh individu. Apabila menampilkan atau tidak menampilkan perilaku tertentu, evaluasi atau penilaian ini dapat bersifat menguntungkan atau merugikan. Konsumen yang memiliki sikap yang positif terhadap makanan organic berdasarkan keyakinan dan evaluasi akan mengkonsumsi makanan organic karena dianggap bermanfaat bagi mereka sehingga menstimulasi niat konsumen membeli makanan organic.

\section{KESIMPULAN}

Beberapa kesimpulan yang dapat diambil dari hasil penelitian ini adalah:

1. Karakteristik dan kondisi sosial ekonomi responden memperlihatkan usia tertinggi: 28$38(43,23 \%)$, pendidikan tertinggi SMP $(42,90 \%)$, pekerjaan utama ibu 
Elfi Rahmadani dan Penti Suryani: Analisis Nilai dan Pengetahuan Ibu-ibu Rumah Tangga sebagai Prediktor Intensi Beli Produk Sayuran Organik di Pasar Modern Kota Pekanbaru

rumah tangga $(49,68 \%)$, jumlah anggota keluarga terbanyak 3-4 orang $(54,84 \%)$ dengan jumlah terbanyak mengkonsumsi 2 sampai $3 x$ dalam seminggu adalah $41,94 \%$ dan pengeluaran terbesar untuk kebutuhan sehari-hari: Rp25.000$30.000,-(48,39 \%)$.

2. Terdapat kesesuaian antara model perilaku beli sayuran organik dengan data penelitian yang menggambarkan pengaruh orientasi alami manusia, pengetahuan organik, dan sikap terhadap makanan organik, terhadap intensi beli sayuran organik.

3. Dari enam variabel pengukuran atau dimensi (X1 sd D3) terbentuk tiga faktor bersama, yaitu faktor bersama satu (F1) dengan persentase variansnya $=24,788 \mathrm{dan}$ faktor bersama dua (F2) dengan persentase varians $=18,33$ dan faktor bersama tiga (F3) dengan persentase variansnya $=17,461$ serta kumulatif persentase varians yang terbentuk dari ketiga faktor bersama adalah sebesar $=60,579$.

4. Hipotesis pertama diterima (6 variabel analisis faktor yang direduksi menjadi 3 faktor membuktikan faktor utama atau F1 yang paling berpengaruh adalah biaya pengeluaran sayur, usia pembeli, jumlah anggota keluarga pembeli, dan kepemilikan rumah, selanjutnya faktor 2 atau F2= Tingkat pendidikan pembeli sayur, dan F3=Banyaknya konsumsi sayur.

5. Semakin tinggi nilai orientasi alami manusia, maka semakin baik juga sikap pada sayuran organik. Pengetahuan organik memiliki pengaruh positif dan signifikan terhadap sikap pada sayuran organik. Hal ini berarti semakin tinggi pengetahuan organik, maka semakin baik juga sikap pada sayuran organik. Sikap pada sayuran organik memiliki pengaruh positif dan signifikan terhadap intensi beli sayuran organik. Hal ini berarti semakin baik sikap pada sayuran organik, maka semakin tinggi intensi beli sayuran organik.

6. Variabel nilai orientasi alami dan sikap terhadap intensi beli sayur organik memiliki validitas dan nilai realibilitas yang positif. Semakin tinggi nilai orientasi alami manusia, maka semakin baik juga sikap pada sayuran organik. Pengetahuan organik juga memiliki pengaruh positif dan signifikan terhadap sikap pada sayuran organik. Demikian juga sikap pada sayuran organik memiliki pengaruh positifdan signifikan terhadap intensi beli sayuran. 


\section{Endnotes}

1 YLKI (2012) YLKI. 2012. Survei Konsumen Organik Indonesia, (http://www.organic indonesia.org/05infodata-news. php?id=443, diakses 1 Maret 2013)

2 Tsakiridou, E., Boutsouki, C., Zotos, Y., \& Mattas, K. 2008. Attitudes and Behaviour towards Organic Products: An Exploratory Study. International Journal of Retail $\mathcal{E}$ Distribution Management, 36(2): 158-175. ${ }^{3}$

Kalafatis, S. P., Michael, Robert, E., \& Markos, H. T. 1999. Green Marketing and Ajzen's Theory of Planned Behavior: A Cross-market Examina-tion. Journal of Consumer Marketing, 16(5): 441-460

4 Chiou, J. S. 1998. The Effects of Attitude, Subjective Norm, and Perceived Behavioral Control on Consumers' Purchase Intentions: The Mode-rating Effects of Product Knowledge and Attention to Social Comparison Information. Proceedings of the National Science Council.

5 Aertsens, J., Verbeke, W., \& Huylenbroeck, G. V. 2009. Personal Determinants of Organic Food Consumption: A Review. British Food Journal, 111(10): 1140-1167.

6 Fotopoulos, C. \& Krystallis, A. 2002. Purchasing Motives and Profile of the Greek Organic Consumer: A Countrywide Survey. British Food Journal, 104(9): 730-765.

7 Fraj\& Martinez, 2006; Environmental Values and Lifestyle as Determining Factors of Ecological Consumer Behaviour: An Emprical Analysis. Journal of Consumer Marketing, 23 (3): 113-114

8 Divine, R. L. \& Lepisto, L. 2005. Analysis of Healthy Lifestyle Consumer.Journal of Consumer Marketing, 22(5): 275-283.

9 Lodorfos, G. N. \& Dennis, J. 2008. Consumers' Intent: In the Organic Food Market. Journal of Food Products Marketing, 14(2): 17-38.

10 Engel, J.F., Roger, D.B., \& Paul, W.M.2005. Consumer Behavior. Dreyden Press.Forth Worth. p.3

11 Brucks, M. 1985. The Effect of Product Class Know-ledge Information Search Behavior. Journal of Consumer Research, 12(1): 1-1

12 Aertsens, J., Verbeke, W., \& Huylenbroeck, G. V. 2009. Personal Determinants of Organic Food Consumption: A Review. British Food Journal, 111(10): 1140-1167.

13 Opcit Engel, J.F., Roger, D.B., \& Paul, W.M.2005.

${ }^{14}$ Gusrini V, Vevi. 2013. Pengaruh Tingkat Pendidikan dan Motivasi Kerja Terhadap Kinerja Pegawai Tata Usaha SMK Negeri di Kota Payakumbuh. Skripsi. Fakultas Ekonomi, Prodi Ekonomi, Universitas Negeri Padang. Padang.
DAFTAR PUSTAKA

Aertsens, J., Verbeke,W., \&Huylenbroeck, G. V. 2009. Personal Determinants of Organic Food Consumption: A Review. British Food Journal, 111(10): 1140-1167.

Ajzen, I. 1991. TheTheory of Planned Behavior.Organizational Behavior and Human Decision Process. USA.

Amyx, D. A., Dejong, P. F., Lin, X. C. G., \& Weiner, J. L. 1994. Influencer of Purchase Intentions for Ecologically Safe Products: An Exploratory Study. The proceeding of the 1994 American Marketing Association's Winter Educators Conference.5, AMA, Chicago,341-344.

Arnould, E. J., Price, L.L., \&Zinkhan, G.M.2004. Consumers.McGrawHill. New York.

Brucks, M. 1985. The Effect of Product Class Know-ledge Information Search Behavior. Journal of Consumer Research, 12(1): 1-1.

Chan, R. Y. K. 1999. Environmental Attitudes and Behavior of Consumers in China: Survey Findings and Implications. Journal of International Consumer Marketing, 11(4): 25-52. 
Elfi Rahmadani dan Penti Suryani: Analisis Nilai dan Pengetahuan Ibu-ibu Rumah Tangga sebagai Prediktor Intensi Beli Produk Sayuran Organik di Pasar Modern Kota Pekanbaru

2001. Determinants of Chinese

Consumers Green Purchase

Behavior. Psychology \&

Marketing, 18(4): 389-413.

Chan, R. Y. K. \& Lau, L. B. Y. 2000. Antecedents of Green Purchases: A Survey in China. Journal of Consumer Marketing, 17(4):338357.

Chen, T. B. \& Chai, L. T. 2010. Attitude Towards the Environment and Green Product: Consumer Perspective. Management Science and Engineer-ing, 4(2): 27-39.

Chiou, J.S. 1998. The Effects of Attitude, Subjective Norm, and Perceived Behavioral Control on Consumers' Purchase Intentions: The Mode-rating Effects of Product Knowledge and Attention to Social Comparison Information. Proceedings of the National Science Council.

Divine, R. L. \& Lepisto, L. 2005. Analysis of Healthy Lifestyle Consumer. Journal of Consumer Marketing, 22(5): 275-283.

Dreezens, E., Martijn, C., Tenbult, P., Kok, G., \& Devries,. 2005. Food and Values: An Examination of Values Underlying Attitudes Toward Genetically Modified and
Organically Grown Food Products. Appetite.

Engel, J.F., Roger, D.B., \& Paul, W.M.2005. Consumer Behavior. Dreyden Press.Forth Worth. p.3.

Fotopoulos, C. \& Krystallis, A. 2002. Purchasing Motives and Profile of the Greek Organic Consumer: A Countrywide Survey. British Food Journal, 104(9): 730-765.

Fishbein\&Ajzen, I. 1975.Belief, Attitude, Intention and Behavior: An Introduction to Theory and Research. Addison-Wes-ley Publishing Company Inc. California.

Fraj\& Martinez, 2006; Environmental Values and Lifestyle as Determining Factors of Ecological Consumer Behaviour: An Emprical Analysis. Journal of Consumer Marketing, 23 (3): 113-114.

Gusrini V, Vevi. 2013. Pengaruh Tingkat Pendidikan dan Motivasi Kerja Terhadap Kinerja Pegawai Tata Usaha SMK Negeri di Kota Payakumbuh. Skripsi. Fakultas Ekonomi, Prodi Ekonomi, Universitas Negeri Padang. Padang.

Junaedi, S. 2007. The Roles of Consumer Knowledge and Emotion Toward 
Ecological Issue: An Empirical Study of Green Study Consumer Behavior. International Journal of Business, 9 (1): 81-99.

Kalafatis, S. P., Michael, Robert, E., \& Markos, H. T. 1999. Green Marketing and Ajzen's Theory of Planned Behavior: A Cross-market Examina-tion. Journal of Consumer Marketing, 16(5): 441-460.

Kerlinger,F.N. 1990. Asas-asas Penelitian Behavioral. Edisi 3. Gadjah Mada University Press, Yogyakarta.

Kotler, P. 2006. Marketing Management. New Jersey. Prentice Hall International, Inc.

Krystallis, A., Vassallo, M., Chryssohoidis, G., \&Perrea, T. 2008.Societal ang Individualistic Drivers as Predictor of Organic Purchasing Revealed through a Portrait Value Questionnaire (PVQ) Based Inventory. Journal of Consumer Behavior .

Laroche, M., Jasmin, B., \& Guido, B. F. 2001.Targeting Consumers Who are Willing to Pay More for Environementally Friendly Products. Journal of Consumer Marketing, 18 (6): 503 - 520.

Lodorfos, G. N. \& Dennis, J. 2008. Consumers' Intent: In the Organic
Food Market. Journal of Food Products Marketing, 14(2): 17-38.

Moreau, C. P., Lehman, D. R., \& Markman, A. B. 2001. Entrenched Knowledge Structure and Consumer Response to New Products. Journal of Marketing Research, 38(1): 14-29.InAertsens,J., Verbeke,W.,\&Huylenbroeck,G. V. 2009. Personal Determinants of Organic Food Consumption: A Review. British Food Journal.

Magistris, T. \&Gracia, A. 2008. The Decision to Buy Organic Food Product in Southern Italy.British Food Journal, 110 (9): 929-947.

Padel\& Foster, C. 2005. Exploring the Gap Between Attitudes and Behaviour: Understanding why Consumeers Buy or Do Not Buy Organic Food. British Food Journal, 107 (8): 606625.

Peter, J. Paul \& Jerry Olson, 2005). Consumer Behavior and Marketing Strategy, 7th Edition. McGraw Hill. New York

Sihombing, S.O. 2007), Predicting Environmentally Purchase Behavior: A Test of the Value-attitude-behavior Hierarchy. The $2^{\text {nd }}$ Indonesia Business Management Confrence, Jakarta. 
Elfi Rahmadani dan Penti Suryani: Analisis Nilai dan Pengetahuan Ibu-ibu Rumah Tangga sebagai Prediktor Intensi Beli Produk Sayuran Organik di Pasar Modern Kota Pekanbaru

Singarimbun, Masri dan Effendi, Sofyan. 1989. Metode Penelitian Survai. LP3ES. Jakarta.

Sugiyono, 2005, Metode Penelitian Kualitatif. Alfabeta. Bandung.

Sunjoyo. et.al. (2013). Aplikasi SPSS untuk SMART Riset (Program IBM SPSS 21.0). Alfabeta. Bandung.

Suprapto, B. \& Wijaya, T. 2012. Intention of Indo-nesian Consumers on Buying Organic Food. International Journal of Trade, Economics and Finance, 3(2): 114119.

Susana, T. 2009. Pengaruh Orientasi Budaya Individual, Jenis Kelamin dan Orientasi Budaya Masyarakat terhadap Gejala Somatisasi dan Depresi Murni. Disertasi. Universitas Gadjah
Mada. Yogyakarta.

Tsakiridou, E., Boutsouki, C., Zotos, Y., \& Mattas, K. 2008. Attitudes and Behaviour towards Organic Products: An Exploratory Study. International Journal of Retail $\mathcal{E}$ Distribution Management, 36(2): 158-175.

Van Den Ban. A.W. dan H.S Hawkins., 1999. Penyuluhan Pertanian. Kanisius. Yogyakarta

Wijaya, T. \& Hidayat, A. 2011.Model Intensi Pembelian Makanan Organik. Call for Paper Update Ekonomi, Akuntansi dan Bisnis Indone-sia, Fakultas Ekonomi UII-Yogyakarta, 28 Juni.

YLKI (2012) YLKI. 2012. Survei Konsumen Organik Indonesia, (http:/ /www.organicindo nesia.org/ 05infodata-news. php?id=443, diakses 1 Maret 2013). 